All searches limited to 25 references with abstracts.

Additional references to be charged as new search.

Members wishing to undertake their own computer searches are requested to telephone in advance to ensure the computer is free.

\section{Old books ofier}

Throughout the year, the process of weeding redundant bookstock for disposal has continued. Members visiting the College are welcome to take any of these books and should contact the Library staff. We regret that it is not possible to supply lists of the books.

\section{Additional journals}

The Library has recently added several new titles to its list of journal holdings. We would like to thank the Royal Society of Medicine for donating copies of their new Journal of Medical Biography, and Dr Paul Bowden for arranging a subscription to the Journal of Forensic Psychiatry. We are also grateful to Dr Max Fink for supplying volumes 1-3 of Convulsive Therapy, and donating the necessary funds for binding our complete collection of this title. Two further journals, Behavioral and Brain Sciences and Psychiatric Clinics of North America, are now being supplied to the Library in exchange for subscriptions to the British Journal of Psychiatry. A complete list of the Library's journal holdings is available on request.

\section{Hospital closures}

With the assistance of Dr Neil Boast, the Library's project to photograph old asylum buildings continues. However, we are concerned that hospitals are closing unbeknown to us and are appealing to members to notify the Library of any planned closures in their area. This will assist us in ensuring that photographic record of these impressive old buildings is retained.

SUSAN Floate Librarian Margaret Harcourt Williams Archivist

Heather WatKINS Senior Library Assistant JONATHON VINES Library Assistant

Psychiatric Bulletin (1993), 17, 636

\title{
College Prizewinners (1993 and previous years)
}

\section{Gillian Page Prize in Adolescent Psychiatry}

1993 No entries received

1991 Dr J. J. Shaw

1989 Dr P. Taylor

\section{Brian Oliver Prize in the Psychiatry of Learning Disabilities}

Established in 1991

1993 Dr J. Curran and Dr S. A. Cooper
1991 Dr M. Roy

\section{Lilly Travelling Fellowship}

1993 Dr C. Hilton

1992 Dr I. T. Bownes

1991 Dr C. Pantelis

\section{Philip Davis Prize in Old Age Psychiatry}

Established in 1991, first prize awarded 1992

1993 Dr J. Warrington

1992 Dr P. L. Huckle

Merck Essay Prize

Established 1993

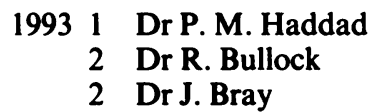

A list of winners of other College prizes appeared in the September issue of the Psychiatric Bulletin. 